\title{
THE LOCATION OF INWARD INVESTMENT, TECHNICAL CHANGE AND SKILLED LABOUR: EVIDENCE FROM THE UNITED STATES
}

\author{
Business School \\ Bournemouth University \\ 89 Holdenhurst Road \\ Bournemouth \\ Dorset \\ BH8 8EB \\ UK \\ awebster@bournemouth.ac.uk
}

Allan Webster

Key words: foreign direct investment, factor proportions, knowledge seeking. JEL: 


\begin{abstract}
This study provides an empirical analysis of US inward foreign direct investment (FDI) with particular reference to the role of skilled labour. The theoretical foundations of the analysis are rooted in OLI theory and, in particular, its locational aspects. However, the empirical techniques employed are e more commonly associated with factor proportions theory. Thus, the contribution of the paper is partly methodological in applying such techniques to the determinants of inward FDI. The paper also produces evidence that US inward FDI is focused on skill intensive economic activities, using multiple categories of skilled labour. It also finds that strategic asset seeking behaviour focused on skilled labour overlaps with efficiency seeking behaviour linked to productivity change, export activity and market seeking behaviour.
\end{abstract}




\section{INTRODUCTION}

The primary objective of this paper is to provide an empirical analysis of the role of skilled and educated labour and the role of technical change in the location of US inward foreign direct investment (FDI) and to analyse the interaction between the two. Although the paper's main interest is in educated labour and technical change the analysis is set within a more general and more traditional factor proportions framework. This is not to say that the analysis presented relies on a theoretical foundation based on factor proportions. In fact it seeks to test locational aspects of Dunning's (1988) OLI theory. Specifically, it is argued that some of the insights from a factor proportions approach have a potentially useful contribution to the understanding of locational aspects of FDI. In this particular case a key contribution is to provide useful tools for empirical analysis. That is, this paper borrows and extends empirical techniques but not theory more commonly associated with the analysis of international trade to provide evidence on the location of FDI.

Although the main interest of this paper is in the influence of educated (skilled) labour and technical change on FDI it is useful to set this in the context of a broader set of factors of production. The paper seeks to test Dunning's (1998) argument with respect to the importance of knowledge seeking motives in the location of FDI. However, its approach is to consider knowledge seeking motives within the broader OLI framework for example, alongside resource seeking and market seeking motives. A number of authors such as Blonigen (2005) have commented on the relative scarcity of empirical research dealing with the determinants of the location of inward FDI. Other authors, such as Pfluger et al (2010), in commenting on research focused on the importance of skilled labour, have suggested there is a need to move away from a simple dichotomy between skilled and unskilled labour. In addition to its methodological approach the contribution of this paper to the literature is to address both of these limitations.

\section{REVIEW OF THE LITERATURE AND HYPOTHESIS DEVELOPMENT}

\subsection{Review of Literature}

Dunning (1998) discussed the difficulties of integrating traditional trade theories with locational aspects of the theory of the Multinational Enterprise (MNE) but expressed the view that: “...the principle of comparative advantage still has much going for it as to how best to allocate scarce resources between countries..”. In this context he made reference to the work of Wood (1993), a study which employs factor content techniques. The paper presented here is very much in this tradition, in that it seeks to employ, adapt and extend factor content techniques to provide a basis for testing the key locational aspects of the OLI (Ownership, Location, Internalisation) theory of foreign direct investment.

Empirical studies which link the factor proportions (Heckscher-Ohlin) theory of international trade to the location of inward foreign direct investment (FDI) are scarce and tend to focus more on outward than inward FDI. Nachum et al (2000) found UK outward FDI to be concentrated in sectors in which the UK exhibited a revealed 
comparative disadvantage. Yeaple (2003) provides an econometric analysis of US outward FDI, linking it to skill endowments and skill intensity. The paper found US outward FDI to be consistent with a comparative advantage in skill intensive industries. This paper shares much in common with Yeaple (2003) but given the emphasis on the location rather than the source of FDI, considers inward FDI. Other studies which link inward FDI to relative factor abundance include Maskus and Webster (1995) and Palanggkaraya and Waldkirch (2008). These studies, like this paper, use factor content techniques to examine the link between inward FDI and factor proportions. However, this study develops this approach further by including factor proportions within econometric tests of a more general theory of inward FDI.

Factor content analysis is an empirical technique and thus can be related to the theory of FDI in a number of different ways. The most obvious link between factor proportions and FDI theory is through the knowledge-capital model of Carr et al (2001) which identifies knowledge intensity with skilled labour intensity. In consequence the model emphasises the role of the abundance of skilled labour relative to unskilled labour, essentially a factor proportions argument. Both the original study and subsequent work, such as that by Mariel et al (2009), find empirical support for the model.

A second link between factor proportions is through a gravity model. Unlike knowledgecapital there is no necessary link in theory between factor proportions and a gravity model. A gravity model might not require a theoretical foundation involving factor proportions but empirical specifications of gravity models often do include differences in factor proportions between countries. This is not always the case. For example, the gravity model estimated by Kleinert and Toubal (2010) includes an explicit term capturing differences in relative factor endowments whereas that by Zwinkels and Beugelsdijk (2009) does not.

Lastly there are many empirical studies of the determinants of inward FDI in particular, which have a variety of different theoretical foundations but which result in variables common to factor proportions specifications. Blonigen (2005) provides a useful review of this literature, noting the tendency to use various intensities (R \& D, advertising, skilled labour) in such empirical models. Chidlow et al (2009) in their study of inward FDI in Poland define a series of efficiency variables including labour endowments and a several knowledge seeking variables, such as educated labour. Driffield et al (2009) link technological influences to productivity and endowments of skilled labour. Villaverde and Maza (2012), in a study of the determinants of Spanish inward FDI, use measures of labour productivity, technological capital, investment in R\&D and human capital. The key point is not that these studies are based on factor proportions theory - they are not. But they do utilise variables that can be analysed using the same techniques as factor proportions models.

A further common feature of empirical models of FDI is a link with both international trade and with productivity. Papadopoulos and Martin (2010) find a link between export performance and internationalisation. Pfuler et al (2010) review existing research linking 
trade, labour markets and FDI. Milner and Pentecost (1996) consider the determinants of inward investment in the UK and found weak support for an influence of host country factor endowments. Driffield (2002), in a paper close in spirit to this one, undertakes an econometric analysis of the determinants of inward investment in the UK and finds agglomeration variables to be more important than comparative advantage in trade. Driffield (2001) provides evidence of the links between inward investment in the UK and productivity growth, which suggests a different dimension to these issues. Driffield and Munday (2002) provide an interesting study of agglomeration, comparative advantage and inward investment in the UK, showing that comparative advantage and inward investment in the UK largely share a common set of determinants.

There is a growing literature on knowledge seeking and inward FDI. For example, Chung and Alcacer (2002) in their analysis of the US find that state level R\&D does not attract FDI in general but does has a powerful effect on firms in R\&D intensive sectors.

Cantwell and Janne (1999) find support for the view that multinational corporations adopt technological strategies in their locational decisions. Cantwell (2009) discusses a progression in locational strategy from the influence of more traditional cost considerations to innovative clusters with specific skills and technology.

This paper has much in common with the knowledge seeking literature in that it too is focused upon the role of technical change and skilled (educated) labour in the location of FDI. Although it shares an emphasis on knowledge seeking it adopts a very different approach. Rather than focusing specifically on the processes behind knowledge seeking investment it considers them within a more general (OLI) context in which, for example, resource seeking and market seeking investment are also considered within a wider framework. To do this it borrows and develops empirical tools from the factor proportions tradition in the analysis of international trade.

\subsection{Development of Hypotheses}

Different theoretical foundations lead to a common prediction with respect to a focus of US inward FDI on skill intensive activities. The knowledge capital model would suggest such a focus based on factor proportions. From the perspective of OLI theory measures of the skill intensity are often used to capture strategic asset seeking behaviour. This means that both theoretical foundations create a common hypothesis - that inward FDI in the US should be focused on skill intensive activities. However, "intensive" in this sense should read "relatively intensive". It only makes sense to define an activity as "skill intensive" by measuring "skill" in relation to other factors and by comparing "skill intensity" in relation to other industries.

Hypothesis 1: US Inward FDI should be focused on economic activities that make intensive use of highly skilled labour relative to other types of labour and other factors of production.

There is another dimension to this. Driffield et al (2009) and others have drawn attention to the link between FDI, productivity and skilled labour. That is, we would expect both 
inward FDI and skilled labour to be associated with higher productivity industries. Using multi-factor productivity, or total factor productivity, to capture these effects gives the second testable hypothesis.

Hypothesis 2: the highest rates of growth of multi-factor productivity in the US occur in those industries which are also intensive in skilled labour.

Note that if both hypothesis 1 and 2 are accepted then a further hypothesis is implied.

Hypothesis 3: US inward FDI should be relatively concentrated in economic activities which exhibit high growth of multi-factor productivity.

A number of empirical studies of FDI address the link between exports and FDI. In the tradition of Buckley and Casson (1976) the choice between exporting and foreign production at the firm level helps determine outward investment. From the perspective of the location of inward investment the perspective is different. The characteristics of a location are, by definition, not at the firm level and it is less obvious that exports and FDI are substitutes from the perspective of a host location. Indeed, a number of studies (see Blonigen, 2005), find evidence of a positive link between inward FDI and exports. Within OLI theory we should expect both resource seeking and efficiency seeking motives of the type described by Dunning (2000) to create a link between inward FDI and exporting, although market seeking motives would have an opposite effect. In terms of the focus of both US trade and inward investment on skilled labour and other factors of production (factor content) this leads to the next hypothesis.

Hypothesis 4: the concentration (factor content) of US inward FDI on skilled labour and other key factors of production should be positively related to the factor content of US net exports.

OLI theory, Dunning (2000), also includes a role for market seeking investment. When expressed in terms of a factor proportions methodology this would suggest a relationship between the factors used most intensively in FDI and those used most intensively in US consumption. A common argument, for example Krugman (2008), is that the US has been subject to skill biased technical change. Both efficiency seeking and strategic asset seeking motives for inward investment suggest a positive relationship between inward FDI and technical change. In consequence we should expect to observe a positive relationship between the factor content of inward FDI and changes in factor proportions. Finally, we should expect to observe a positive relationship between the factor content of FDI and the demand for each factor of production. This is not intended to have a strong theoretical foundation but to act as a control variable. That is, some factors of production will be more widely used throughout the US economy. For example, senior professionals and managers are likely to be systematically smaller in number than lesser skilled workers across the economy. He purpose of this control variable is to pick up any effects resulting from the fact that some factors are simply more widely used across the whole economy than others. 
Hypothesis 5: the factor content of US inward FDI should be positively related to (a) the factor content of US consumption, (b) skill (factor) biased changes in production techniques and (c) overall factor demands.

\section{METHODOLOGY}

\subsection{The Factor Content of Trade}

The traditional factor content or Heckscher-Ohlin-Vanek (HOV) model, Vanek (1968), can be stated as follows:

$$
\text { A.T }=\mathrm{V}-\mathrm{s} . \mathrm{V}_{\mathrm{w}}
$$

where $\mathrm{A}$ is a ( $\mathrm{kx} \mathrm{n})$ matrix of factor requirements, giving the amount of each of $\mathrm{k}$ factors needed to produce one unit of each of $n$ outputs, $T$ is a ( $\mathrm{n} x 1$ ) vector of net exports of (exports less imports) each sector, $\mathrm{V}$ is the $(\mathrm{k} \mathrm{x} 1)$ vector of domestic factor supplies, $\mathrm{V}_{\mathrm{w}}$ the comparable vector of world factor supplies and $\mathrm{s}$ a scalar given by the ratio of domestic to world GDP.

The data requirements for accurately measuring both domestic and world supplies of factors of production are so demanding as to preclude most authors from even attempting to measure domestic factor supplies $(\mathrm{V})$ and world factor supplies $\left(\mathrm{V}_{\mathrm{w}}\right)$. Vanek (1968) shows that, given a number of strong assumptions, the relationship described by equation 1 allows us to use the left hand side (AT - the "factor content" of trade) to infer the right hand side (comparative factor abundance). Obtaining data to measure the factor content remains a challenging task but much less so than trying to measure world factor supplies. For these reasons the factor content model has a long tradition in empirical studies of international trade and factor proportions.

As a consequence of the strong assumptions needed to ensure that the factor content of trade precisely reflects international differences in factor endowments this approach has been under significant attack from a number of authors. The detailed issues are not described here for reasons of brevity but interested readers are referred to Trefler (1995) and Leamer (2000). More recently, see Krugman (2000), the factor content model has had a wider acceptability restored through a re-interpretation of its meaning and the model retains validity as a tool of analysis for the study of international trade and the implications for FDI.

For the purposes of this paper the factor content model is interpreted much more in line with the spirit of Dunning's (1998) and Wood's (1993) "guiding light”. That is, this paper employs factor content techniques without necessarily assuming a comparative advantage framework. Specifically, equation 1 postulates a theoretical relationship between the factor content of trade (AT from equation 1) and international differences in factor endowments. However, if we disregard this theory and focus solely on AT (the factor content of trade) we still have a measure of the services of factors of production used in net exports, that is, those employed to produce the goods that are actually exported and imported. For the purposes of this paper we use the factor content of trade 
as a measure and not as a test of a particular theory. It defines which factors of production are most and which least used in international trade. This is taken as being consistent with more than one theoretical explanation. For example, both competitive advantage and comparative advantage could be used to explain specialisation in sectors relatively intensive in certain factors, particularly when these factors include labour skills.

In conducting factor content studies of comparative advantage Leamer (1980) has shown that, even if some of the strong assumptions of the HOV model are violated, the ranking of factors according to the factor content of trade relative to the factor content of consumption continues to reflect comparative advantage. Although this paper does not necessarily tie the observed factor content of trade uniquely to comparative advantage this remains a useful property and factor content results are reported accordingly.

Finally, factor content studies came under significant criticisms in the late 1990s. Krugman (2008) suggests a re-interpretation of the model (as the difference between reality and a hypothetical counter-factual) that overcomes much of this criticism.

Nonetheless, as Krugman (2008) notes, the data requirements of factor content studies are considerable and data availability imposes limitations on such analysis, not least with respect to the level of aggregation used.

\subsection{Testing the OLI theory}

A number of authors including, for example, Driffield (2002), have taken the approach of specifying an econometric relationship between FDI and a series of determinants at the level of individual sectors. For the purposes of this paper a similar relationship is presumed but not estimated. That is, the model estimated here assumes, as a preliminary step, a relationship of the following type at the level of the sector:

$$
` \mathrm{FDI}=\lambda_{0}+\lambda_{1} \cdot \mathrm{T}+\lambda_{2} \cdot \mathrm{C}+\lambda_{3} \cdot \mathrm{TFP}+\lambda_{4} \cdot \mathrm{FD}+\lambda_{5} \cdot \mathrm{PF}
$$

where FDI is a ( $\mathrm{n} x 1)$ vector of inward investment in each of $\mathrm{n}$ sectors, $\mathrm{T}$ is a (n x1) vector of net exports for each sector, $\mathrm{C}$ the vector of domestic consumption for each sector, MFP the ( $\mathrm{n} \times 1$ ) vector of multi (total) factor productivity indices for each sector, FD the vector of relative factor demands of each sector and PF the proportionate change in relative factor intensities from the previous year for each sector.

The model seeks to explain inward FDI in terms of the location aspects of the OLI paradigm in the following way. Firstly FDI is linked to net exports (T), capturing the pattern of specialisation in international trade generated by the same resource seeking and efficiency seeking characteristics that stimulate inward investment. Next it is linked to a market size variable (C), the total consumption of each sector's output. This is intended to capture market seeking aspects of OLI theory. The variable FD measures the demand for factors of production, relative to unskilled labour. Finally the model seeks to capture the more dynamic "knowledge seeking" aspect of OLI theory with two technological change variables. MFP is a multi (total) factor productivity index, discussed further in section 3.3 below and PF is a measure of the proportionate change in relative factor intensities for 
each sector. For the purposes of exposition and simplicity only this is assumed to involve only two factors of production, giving a single ratio. More factors are introduced at the next step. This latter variable is intended to capture the effects of, in particular, skill biased technological progress but also any type of factor biased technical change.

Since the concern of this paper is the role of labour skills and education in particular and factors of production more generally equation 2 (measured in goods markets) needs to be converted to an equivalent expression in terms of factors of production. This is achieved by premultiplying both sides of equation 2 by the $(\mathrm{kx} n)$ factor requirements matrix $\mathrm{A}$. This gives the model to be estimated as:

$$
\text { A.FDI }=\beta_{0}+\beta_{1} \cdot(\mathrm{A} . \mathrm{T})+\beta_{2} \text {.(A.C) }+\beta_{3} \cdot(\mathrm{A} \cdot \mathrm{TFP})+\beta_{4} . \mathrm{PFP}+\beta_{5} \text { (A.FD) }
$$

The interpretation of the ( $\mathrm{k} \times 1)$ vectors (A.T) and (A.C) are standard - they are the factor contents of net exports and of consumption. The dependent variable (A.FDI) is the factor content of inward investment as used, for example, in Maskus and Webster (1995). The factor content of inward FDI provides a measure of the extent to which inward FDI is concentrated in sectors intensive in particular factors of production. Thus, for example, it would identify where FDI is focused in sectors making intensive use of natural resources. In its particular application in this study it also provides some evidence of knowledge seeking investment in that factors are defined to include highly skilled and highly educated categories of labour. However, the factor content of inward FDI is solely a measure of the focus of inward FDI on sectors intensive in particular factors and does not have the same theoretical foundations as the factor content of trade.

Equation 3 includes two terms intended to capture the effects of technical change on inward FDI. The variable (A.MFP) captures the effects of sector level changes in multi factor productivity on factor markets. The variable PFP uses proportionate changes in relative factor intensities to capture the effects of factor biased technical change. Both variables are explained in more detail in section 3.3 below.

The variable FD captures the demand for each factor of production relative to least skilled labour. This variable is intended to operate as a control variable - to capture the effects of those factors which are simply more widely used throughout the economy.

\subsection{Technical Change}

Traditional economic theory relating to exogenous technical change has tended to identify two main types of process - Hicks neutral (technical progress which does not alter factor proportions) and factor biased (in which factor proportions change). One point that has been made for some time (see, for example, Leamer, 1996) is that, even where technical change is Hicks neutral, it does not follow that the impact on factor markets is neutral. That is, technical change could, hypothetically, be such that it does not change factor proportions in any sector. Nonetheless if such Hicks-neutral technical change is focused on sectors which are, say, intensive in skilled labour then technical change would still tend to favour skilled labour across the economy as a whole. A good discussion of this is 
provided in Haskel (2000). To attempt to measure such effects this paper uses the factor composition of multi (total) factor productivity (FMFP). This is defined as:

$$
\mathrm{FMFP}=\mathrm{A} \cdot \mathrm{MFP}
$$

where $\mathrm{A}$ is the ( $\mathrm{k} \mathrm{x} \mathrm{n)}$ matrix of factor requirements (noted above) and MFP a ( $\mathrm{n} \mathrm{x} \mathrm{1)}$ vector of multi factor productivity changes for each of $\mathrm{n}$ sectors.

The effect of equation 4 is to take Hicks-neutral technical changes at the level of individual sectors and convert it into the implications for different factors of production. In effect, it produces weighted averages of proportionate changes in MFP for each factor with the weights being the share of the factor in the total output of each sector. These provide measures of the extent to which sector biases in Hicks neutral technical change can create differential effects on factors of production, similar to the process described by Haskel (2000).

The model specified by equation 3 also includes a second variable intended to capture the effects of technical change. This is the variable PFP which is defined as the proportionate change in factor proportions (relative factor intensities) in overall production from the previous year. It is calculated by taking the ( $\mathrm{kx} 1)$ vector of factor contents of output (FCQ) for each sector such that;

$$
\mathrm{FCQ}=\mathrm{A} \cdot \mathrm{Q}
$$

where $\mathrm{a}$ is the ( $\mathrm{kx} \mathrm{n}$ ) factor requirements matrix and $\mathrm{q}$ the ( $\mathrm{n} \mathrm{x}$ 1) vector of outputs for each sector.

To derive the relative factor intensity of output for each year the individual elements of the vector FCQ are divided by the element (factor content of output) for the lowest skill category of labour. The result is a vector of $(k-1)$ factor intensities relative to least skilled labour. The variable PFP is defined as the proportionate change in each element of this vector from the previous year - that is, the proportionate change in the factor intensity (relative to unskilled labour) of output.

The inclusion of a variable intended to capture the effects of factor biased technical change owes much to the extensive literature on skill biased technical change, where such measures have been widely used. As Machin (2001) notes much of the existing evidence on skill biased technical change uses the share of skilled workers in the total wage bill or in total employment and uses the example of the relation between graduate wages and computer usage. The tradition of using within-industry changes in the shares of skilled labour to capture the effects of skill based technical change, amongst other measures, dates from Berman, Bound and Griliches (1994) and Berman, Bound and Machin (1998). Many of these studies, such as Piva et al (2005), implicitly or explicitly define two types of labour - "skilled and unskilled" - and consider changes between the two. The variable defined here is very similar but considers multiple skill categories of labour and other factors of production. Many of these studies also consider the relationship between changes in, for example, the use of computers and the relative share of skilled labour. In 
the framework here these effects are also captured since we include computer equipment as a factor of production.

\section{DATA}

\subsection{Inward FDI Flows and Stocks}

Data on inward FDI in the US were downloaded from the Foreign Direct Investment in the United States database from the Bureau of Economic Analysis, US Department of Commerce. The variable used was the Direct Investment Position on a Historical Cost Basis (stocks). A small number of observations were suppressed on confidentiality grounds. Since, the FDI data needed to be matched with the US input-output data some sectors were combined to a more aggregate category for which FDI data were available. In an even smaller number of cases it was necessary to make assumptions in order to fill gaps in the remaining data.

\subsection{Multifactor (Total) Productivity Indices}

Multifactor productivity indices were downloaded directly from the KLEMS database provided by the US Bureau of Labor Statistics. The Bureau of Labor Statistics (BLS) calculates Tornqvist chained indices for all manufacturing and all non-manufacturing sectors separately. Almost all sectors correspond directly with US input-output categories. Full details of the way in which these indices were calculated are available on the BLS website.

\subsection{Labour Requirements}

The calculation of factor contents requires a factor requirements (A) matrix. The starting point is an input-output table, which provides data on requirements of capital, natural resources and labour in aggregate. To include any analysis according to different categories of labour (for example, "skilled” versus “unskilled”) it is necessary to obtain additional data to provide disaggregation of total labour requirements.

The data for this purpose were downloaded from the Occupational Employment Statistics (OES) database provided by the US Bureau of Labor Statistics. This database provides data on wages and employment for each of about 800 occupational categories in about 200 "industries". Working with a database of this size is daunting but it does allow the data to be aggregated very accurately into desired sector and occupational groupings. The first step in this was to aggregate by sector to match the US input-output classification. Next the data on employment and wages were combined to obtain estimates of the share of each of the 800 or so occupational categories in the total payroll. These shares were then applied to the total labour requirements of the input output table to give the share of each in total output. These data provided the basis for aggregation into the chosen classification of labour.

The data in the OES database is classified according to the US Standard Occupational Classification (SOC). To provide a basis for comparison with other countries these data 
were reclassified to the United Nations International Standard Classification of Occupations (ISCO88) using a concordance between the two provided by the Bureau of Labor Statistics. Since the two do not match exactly there was a risk of some loss of accuracy in this process. The first labour classification used was, therefore, according to the 9 aggregate groupings defined in the ISCO88 classification.

The US Bureau of Labor Statistics also issues a classification of each of the 800 occupations according to the typical requirements in terms of education and experience to be able to work in such an occupation. These are defined in 11 categories from a doctoral degree to short term on the job training. A full list is in Tables 1 and 3 below. Note that these categories do not claim that the relevant workers all have a certain level of education or experience. The data are based on the employment and wages of workers in an occupation for which the listed education and experience would typically be necessary.

\subsection{Input-Output Data}

Data for most of the factor requirements (A) matrix (factors other than labour and aggregate labour requirements) were from Input-Output Accounts Data from the Bureau of Economic Analysis, US Department of Commerce. Data for net exports and for US consumption were also from this source.

\subsection{Regression variables}

For the regression analysis the dependent variable (described in section 4.1) was:

- $\quad$ FIS - the factor content of stocks of inward FDI, given by the term (A.FDI) in equation 3 but where FDI is measured as stocks.

The explanatory variables used were:

- $\mathrm{AT}$ - the factor content of US net exports, as described in section 3.1,

- AC - the factor content of US consumption, the term (A.C) from equation 3,

- FMFP - the factor composition of multi-factor productivity change, as defined by equation 4,

- $\quad$ RFP - relative factor proportions, as defined in section 3.3

- $\mathrm{PFP}$ - the proportionate change in factor proportions, also as described in section 3.3.

For the regression analysis two different samples were used - one in which different categories of labour were defined according to the educational requirements of their occupation and the other in which they were defined by occupation. Further details of each are given in section 4.3 above. Table 1 reports the correlation matrix for these variables for both samples. 


\begin{tabular}{|c|c|c|c|c|c|c|}
\hline \multicolumn{7}{|c|}{ Using labour categories defined by educational requirements } \\
\hline & FIS & AT & $A C$ & FMFP & RFP & PFP \\
\hline FIS & 1 & & & & & \\
\hline AT & -0.0554 & 1 & & & & \\
\hline$A C$ & 0.5439 & -0.0401 & 1 & & & \\
\hline FMFP & 0.4232 & -0.1257 & 0.862 & 1 & & \\
\hline RFP & 0.475 & 0.0367 & 0.9883 & 0.8671 & 1 & \\
\hline PFP & -0.0367 & 0.039 & -0.0252 & -0.0889 & -0.0129 & 1 \\
\hline \multicolumn{7}{|c|}{ Using labour categories defined by occupation (US SOC) } \\
\hline & FIS & AT & $A C$ & FMFP & RFP & PFP \\
\hline FIS & 1 & & & & & \\
\hline AT & -0.0639 & 1 & & & & \\
\hline$A C$ & 0.548 & -0.1225 & 1 & & & \\
\hline FMFP & 0.4628 & -0.1413 & 0.9672 & 1 & & \\
\hline RFP & 0.4664 & -0.0708 & 0.9874 & 0.9757 & 1 & \\
\hline PFP & -0.1436 & 0.035 & -0.1094 & -0.0938 & -0.0535 & 1 \\
\hline
\end{tabular}

\section{THE FACTOR CONTENT OF US INWARD FDI}

This section identifies the key characteristics of inward investment in the US with respect to factor markets over the period 2002-2008. Iit seeks to identify whether or not inward FDI in the US is concentrated in sectors intensive in one particular factor of production or not. For example, evidence that US inward FDI is focused in sectors that are relatively intensive in natural resources would suggest the importance of resource seeking motives. Of more particular interest is whether investment is most heavily focused in sectors making intensive use of highly skilled or highly educated labour and in sectors making use of computer equipment. Evidence that US inward FDI is relatively intensive in both would suggest support for knowledge seeking motives for investment.

Table 1 presents an analysis of the factor content of US inward FDI in two different ways. Firstly, it shows average annual rankings (by factor) of the factor content of US FDI relative to that of the least skilled labour category for the period 2002-2008. Secondly it shows comparable rankings by the factor content of inward US FDI relative to the factor content of consumption. Of the two the ranking by the factor content of FDI relative to that of consumption is probably the more reliable indicator of the relative factor intensity of US inward FDI. In both cases results are reported separately for FDI flows and stocks.

With respect to labour the results are presented according to two different classifications of labour - (a) according to the UN's occupational classification (ISCO88) and (b) with occupations reclassified according to the educational requirements to perform them. This latter measure was discussed at more length in section 4 above. The analysis also includes: 
- three categories of natural resources,

- real estate, and

- five categories of capital, of which computers and electronic equipment are of particular note.

Some care is needed in interpreting these results. For example, a finding that inward FDI in the US is focused on "mining" does not mean that investment is focused in the mining sector. Rather it means that US inward FDI is focused in sectors which make intensive use of the outputs of the mining sector. Note also that Table 2 reports means of annual rankings. In some cases two factors have the same mean and, hence, appear to have the same ranking. Likewise some ranks appear to be missing where two factors have the same mean ranking. For example, in the upper part of the last column of the table there are three factors with a mean rank of 7 and none with a mean rank of 2 or 3 . 


\begin{tabular}{|c|c|c|}
\hline \multicolumn{3}{|c|}{ TABLE 2: RANKINGS OF US INWARD FDI STOCKS BY FACTOR, ANNUAL MEANS 2002-2008 } \\
\hline Factor description & \begin{tabular}{|l} 
Factor intensity \\
relative to lowest \\
skilled labour
\end{tabular} & $\begin{array}{l}\text { Factor content of } \\
\text { inward FDI relative } \\
\text { to consumption }\end{array}$ \\
\hline \multicolumn{3}{|l|}{ With labour by ISCO88 occupational categories } \\
\hline Forestry \& Fishing & 16 & 15 \\
\hline Oil and gas & 7 & 11 \\
\hline Mining & 14 & 4 \\
\hline Real Estate & 8 & 13 \\
\hline Machinery & 13 & 7 \\
\hline Computers \& Electronic Equipment & 12 & 9 \\
\hline Electrical Equipment & 15 & 13 \\
\hline Transport Equipment & 11 & 11 \\
\hline Renting \& leasing (other than real estate) & 10 & 5 \\
\hline Legislators, senior officials, managers & 2 & 4 \\
\hline Professionals & 1 & 7 \\
\hline Techncians, associate professionals & 9 & 13 \\
\hline Clerks, administrators & 4 & 7 \\
\hline Service, shop, sales workers & 3 & 8 \\
\hline Skilled agricultural and fishery workers & 17 & 15 \\
\hline Craft and related workers & 6 & 13 \\
\hline Plant and machine operators, assemblers & 5 & 7 \\
\hline Elementary occupations & $\mathrm{n} / \mathrm{a}$ & 11 \\
\hline \multicolumn{3}{|c|}{ With labour by the educational requirements of occupations } \\
\hline Forestry \& Fishing & 19 & 15 \\
\hline Oil and gas & 5 & 12 \\
\hline Mining & 14 & 4 \\
\hline Real Estate & 6 & 14 \\
\hline Machinery & 12 & 8 \\
\hline Computers \& Electronic Equipment & 10 & 10 \\
\hline Electrical Equipment & 15 & 13 \\
\hline Transport Equipment & 9 & 11 \\
\hline Renting \& leasing (other than real estate) & 8 & 6 \\
\hline Doctoral degree & 18 & 14 \\
\hline Master's degree & 17 & 14 \\
\hline First professional degree & 16 & 17 \\
\hline Bachelor's or higher degree + work experience & 2 & 4 \\
\hline Bachelor's degree & 1 & 5 \\
\hline Associate degree & 13 & 15 \\
\hline Postsecondary vocational award & 11 & 15 \\
\hline Work experience in a related occupation & 3 & 5 \\
\hline Long-term on-the-job training & 7 & 10 \\
\hline Moderate-term on-the-job training & 4 & 7 \\
\hline Short-term on-the-job training & $\mathrm{n} / \mathrm{a}$ & 11 \\
\hline
\end{tabular}


The results in Table 2 show a clear and consistent pattern of US inward FDI focused on sectors which make intensive use of high skilled or highly educated labour. In terms of occupational categories both senior managers and professional workers are highly ranked according to all four of the measures. In terms of educational requirements workers in occupations needing a Bachelors degree or a Bachelors degree with work experience are highly ranked according to all four measures. These findings provide evidence to suggest that US inward FDI is focused on sectors making use of skilled (educated) labour.

Computers and electronic equipment tends to be quite highly ranked for inward stocks but less so for inward flows. The evidence is not conclusive but implies that past investment has intended to be more focused on computer intensive sectors than more recent inflows. Nonetheless, even in terms of flows, US inward FDI remains much more focused on sectors making intensive use of computer and electronic equipment than for almost all other types of capital. When taken in conjunction with the findings for skilled labour, these results suggest that knowledge seeking is an important but not the sole motive underlying inward investment in the US.

Some other findings in Table 2 are also noteworthy. Inward stocks of FDI into the US appear to be focused on sectors which make intensive use of the outputs of the mining sector. With respect to flows there is very little such evidence - inward FDI flows are focused on the use of almost any other factor than the outputs of mining. This evidence is not conclusive but strongly suggests resource seeking investment to have been important in the past but now declining.

The results also suggest that a categorisation of labour into "skilled" and "unskilled" or "highly educated" and "less educated" is too simplistic. This is most clearly seen when labour is classified by the educational requirements of occupations. FDI is indeed focused on industries using highly educated workers, particularly with a Bachelor's degree (with and without experience). But workers in occupations requiring the highest level of academic qualification (Doctorates, Masters and the like) are consistently amongst the lowest ranked factors of production. This is not hard to explain without altering the basic insight that inward FDI in the US is linked to highly educated workers. Those sectors for which Masters Degrees and Doctorates are required for a high proportion of workers tend to be those which, for quite separate reasons, are not highly attractive to investors education and health services in particular.

\section{TOTAL FACTOR PRODUCTIVITY MEASURES}

Since a key emphasis of this paper is on examining evidence for knowledge seeking motives in inward US FDI some indications of technical change are important. Table 3 presents mean annual percentage changes in multifactor (total factor) productivity for a selection of sectors of the US economy. These were calculated from indices published by the US Bureau of Labor Statistics. 


\begin{tabular}{|c|c|c|c|c|c|}
\hline \multicolumn{3}{|c|}{$\begin{array}{l}\text { TABLE 3: US SECTORS WITH HIGH AND LOW MULTIFACT } \\
\text { Sectors with the highest mean MFP change 2004-2008 }\end{array}$} & \multicolumn{3}{|c|}{ Sectors with the lowest mean MFP change 2004-2008 } \\
\hline \multirow[t]{2}{*}{ Description } & \multicolumn{2}{|c|}{ Mean \% change: } & \multirow{2}{*}{ Description } & \multicolumn{2}{|c|}{ Mean \% change: } \\
\hline & \multicolumn{2}{|c|}{ 1998-2008 2004-2008 } & & \multicolumn{2}{|c|}{\begin{tabular}{|l|l|}
$1998-2008$ & $2004-2008$ \\
\end{tabular}} \\
\hline Computer and electronic products & $10.14 \%$ & $10.82 \%$ & Retail trade & $1.56 \%$ & $-0.20 \%$ \\
\hline Insurance carriers and related activities & $1.95 \%$ & $8.54 \%$ & Educational services & $-0.09 \%$ & $-0.30 \%$ \\
\hline Water transportation & $1.95 \%$ & $7.48 \%$ & Real estate & $-0.45 \%$ & $-0.31 \%$ \\
\hline Apparel and leather and allied products & $2.72 \%$ & $6.85 \%$ & Rail transportation & $1.41 \%$ & $-0.38 \%$ \\
\hline Air transportation & $2.81 \%$ & $5.27 \%$ & Legal services & $-0.17 \%$ & $-0.39 \%$ \\
\hline Broadcasting and telecommunications & $1.61 \%$ & $4.30 \%$ & Plastics and rubber products & $0.47 \%$ & $-0.58 \%$ \\
\hline Textile mills and textile product mills & $1.51 \%$ & $3.53 \%$ & Primary metals & $0.19 \%$ & $-0.59 \%$ \\
\hline Miscellaneous manufacturing & $1.76 \%$ & $3.34 \%$ & Ground passenger transportation & $0.08 \%$ & $-0.60 \%$ \\
\hline Computer systems design and related & $1.65 \%$ & $3.16 \%$ & Performing arts, sports, museums. & $1.18 \%$ & $-0.72 \%$ \\
\hline Motion picture and sound recording & $0.47 \%$ & $2.94 \%$ & Accommodation & $0.39 \%$ & $-0.86 \%$ \\
\hline Amusements, gambling, and recreation & $-0.02 \%$ & $2.38 \%$ & Nonmetallic mineral products & $0.00 \%$ & $-1.14 \%$ \\
\hline Farms & $1.86 \%$ & $1.88 \%$ & Securities, commodity contracts etc & $4.41 \%$ & $-1.35 \%$ \\
\hline Printing and related support activities & $0.48 \%$ & $1.80 \%$ & Petroleum and coal products & $1.09 \%$ & $-1.44 \%$ \\
\hline Other transportation \& support activitie & $0.28 \%$ & $1.79 \%$ & Credit intermediation and related & $-1.00 \%$ & $-1.69 \%$ \\
\hline Motor vehicles, bodies, trailers etc & $0.45 \%$ & $1.74 \%$ & Support activities for mining & $1.02 \%$ & $-1.94 \%$ \\
\hline Other transportation equipment & $0.45 \%$ & $1.74 \%$ & Rental and leasing services & $-2.99 \%$ & $-2.11 \%$ \\
\hline Machinery & $-0.18 \%$ & $1.67 \%$ & Construction & $-0.58 \%$ & $-2.41 \%$ \\
\hline Publishing industries (incl. software) & $1.83 \%$ & $1.63 \%$ & Management of companies & $-0.43 \%$ & $-2.66 \%$ \\
\hline Funds, trusts, other financial vehicles & $0.56 \%$ & $1.62 \%$ & Oil and gas extraction & $-1.26 \%$ & $-4.04 \%$ \\
\hline Information and data processing & $-0.15 \%$ & $1.41 \%$ & Mining, except oil and gas & $0.93 \%$ & $-4.80 \%$ \\
\hline \multicolumn{4}{|c|}{ Source: derived from US Bureau of Labor Statistics MFP database (KLEMS) } & & \\
\hline
\end{tabular}

Some of the sectors identified with high rates of multifactor productivity (MFP) growth are no surprise. Computer hardware, computer services and broadcasting and telecommunications are all sectors that are intuitively obvious. However, the inclusion of textiles, apparel and farms was much less expected. The sectors with low mean percentage changes in MFP also contain some sectors which would cause few surprises. The inclusion of mining, oil and gas and retailing are perhaps expected while the inclusion of credit intermediation is much less obvious.

Table 4 translates the MFP indices at the level of the sector into the implications for factors of production. The procedure employed was described in Section 3.3 above. To summarise, MFPs measure Hicks neutral technical change which, by definition, leaves factor proportions unchanged in any one sector. However, some sectors are subject to higher rates of MFP growth than others (referred to as sector biased technical change in the literature), which affects some factors more than others. For example, suppose that sectors intensive in skilled labour benefit from more favourable MFP growth than other sectors. The effect on factor markets has similar effects to skill biased technical change (an increase in the relative demand for skilled labour) but its causes are very different. To capture this Table 3 measures the factor composition of changes in sector MFPs. For each factor $(\mathrm{k})$ this is equivalent to taking the weighted averages of sector MFPs using the share of factor $k$ in the output of each sector as weights. 


\begin{tabular}{|l|c|c|}
\hline TABLE 4: FACTOR COMPOSITION OF US MFP CHANGES \\
\hline Factor Description & Mean annual $\%$ change \\
\hline & $2002-2008$ & $2005-2008$ \\
\hline Forestry \& Fishing & $0.66 \%$ & $0.46 \%$ \\
\hline Oil and gas & $1.41 \%$ & $-2.13 \%$ \\
\hline Mining & $-0.16 \%$ & $-0.65 \%$ \\
\hline Real Estate & $1.12 \%$ & $0.56 \%$ \\
\hline Machinery & $0.12 \%$ & $-0.05 \%$ \\
\hline Computers \& Electronic Equipment & $2.70 \%$ & $2.07 \%$ \\
\hline Electrical Equipment & $0.35 \%$ & $0.23 \%$ \\
\hline Transport Equipment & $1.19 \%$ & $1.11 \%$ \\
\hline Renting \& leasing (other than real estate) & $0.61 \%$ & $-0.22 \%$ \\
\hline Labour classed by occupation (ISCO88): & & \\
\hline Legislators, senior officials, managers & $2.71 \%$ & $1.22 \%$ \\
\hline Professionals & $5.23 \%$ & $2.85 \%$ \\
\hline Techncians, associate professionals & $0.89 \%$ & $0.40 \%$ \\
\hline Clerks, administrators & $2.66 \%$ & $1.26 \%$ \\
\hline Service, shop, sales workers & $1.70 \%$ & $1.38 \%$ \\
\hline Skilled agricultural and fishery workers & $0.15 \%$ & $0.10 \%$ \\
\hline Craft and related workers & $1.54 \%$ & $0.23 \%$ \\
\hline Plant and machine operators, assemblers & $3.00 \%$ & $1.58 \%$ \\
\hline Elementary occupations & $0.54 \%$ & $-0.18 \%$ \\
\hline Labour classed by the educational requirements of & occupations: \\
\hline Doctoral degree & $0.05 \%$ & $-0.04 \%$ \\
\hline Master's degree & $0.06 \%$ & $-0.03 \%$ \\
\hline First professional degree & $-0.02 \%$ & $-0.26 \%$ \\
\hline Bachelor's or higher degree, plus work experience & $2.57 \%$ & $1.13 \%$ \\
\hline Bachelor's degree & $4.20 \%$ & $2.13 \%$ \\
\hline Associate degree & $0.63 \%$ & $0.28 \%$ \\
\hline Postsecondary vocational award & $1.11 \%$ & $0.93 \%$ \\
\hline Work experience in a related occupation & $2.27 \%$ & $1.23 \%$ \\
\hline Long-term on-the-job training & $0.97 \%$ & $0.48 \%$ \\
\hline Moderate-term on-the-job training & $3.05 \%$ & $1.38 \%$ \\
\hline Short-term on-the-job training & $3.51 \%$ & $1.61 \%$ \\
\hline
\end{tabular}

Table 4 has some interesting results,particularly with respect to the factors that benefit from the highest rates of MFP growth. The results suggest that the highest rates of MFP growth in the US economy over the period 2002-2008 are in sectors which make relatively intensive use of computers and electronic equipment and highly skilled labour (senior managers and professionals) or highly educated workers (those in occupations requiring a bachelor's degree, with or without experience). Again, this is probably a more reassuring finding than a surprising one. Nonetheless, what is noteworthy is that these are the same factors in which US inward FDI tends to be greatest. That is, the evidence suggests that inward FDI is focused on sectors with are simultaneously intensive in skills and subject to high MFP growth. 
Sectors with a high proportion of workers whose occupation requires higher and professional degrees are not only under-represented in inward FDI but also tend to have low growth in MFP. As Table 4 shows the aggregate effect on workers requiring higher or professional degrees was negative over the period 2005 to 2008. This can be explained by the low rates of MFP growth shown by, for example, educational and legal services (see Table 3).

\section{REGRESSION ESTIMATES}

Table 5 presents the results of regression analysis of the model specified in equation 3 (see section 3.2) using stocks of US inward FDI as the dependent variable. This specification is effectively a statement of the locational component of the OLI theory, measured in embodied factors of production rather than by industry. Two separate sets of regressions were estimated - one with labour classified according to the educational requirements of occupations and the other using the ISCO88 occupational classification.

In each case three different estimators were used - (a) a common pooled OLS estimator, (b) a double fixed effect panel estimator and (c) a GMM (Arellano Bond) estimator. The use of different estimators allows us to assess the extent to which the different assumptions implied by each estimator. Thus, results which are broadly consistent between one estimator and another suggest that the relevant findings are robust with respect to the choice of estimator. Inevitably using different estimators will also result in different conclusions with respect to some variables. In these cases greater emphasis is placed on the panel (fixed effects) and GMM models.

The results presented in Table 5 show a statistically significant (at 99\% confidence) and positive relationship between the factor content of inward FDI stocks (FIS) and that of net exports (AT) according to both the pooled (OLS) and panel estimators but not the GMM estimator. This applies whether labour is classified by educational requirements or by occupation. With respect to the pooled and panel estimates these findings suggest that US net exports are focused upon industries intensive in the same factors of production as US inward FDI. Since it was earlier established that US inward FDI is focused on skill intensive activities this implies that US exports are similarly focused. In this sense the findings suggest an overlap between strategic asset seeking and resource seeking and efficiency seeking motives.

The estimated coefficients with respect to the factor content of consumption (AC) are statistically significant (at 99\%) according to all three estimators. Again this applies whether or not labour is classified by educational requirements or by occupation. This suggests that a significant overlap exists between strategic asset seeking and market seeking behaviour with respect to US inward FDI.

For the factor composition of multifactor productivity the estimated coefficients are statistically insignificant according to all three estimators whether or not labour is classified by educational requirements or by occupation. There is one exception to this - the coefficient was found to be statistically significant only for the sample using labour classified by occupation and only using the fixed effects panel estimator. The lack of a statistically 
significant relationship in general suggests that the evidence does not support a relationship between stocks of inward FDI and the factor composition of (multifactor) productivity change.

The remaining two variables - Factor Proportions (RFP) and the Proportionate Change in Factor Intensity (PFP) - are related in that the latter is the proportionate change in the former. For the sample using labour classified by educational requirements the estimated coefficient for the factor proportions is negative and statistically significant according to both pooled and panel estimators but not significant with the GMM estimator. For the estimated coefficient for the PFP the findings are reversed - statistically insignificant with the pooled and panel models but positive and statistically significant with the GMM estimator. This is to be expected as in static models the pooled and panel estimators are more likely to be associated with static factor proportions whereas the GMM estimator is dynamic and, hence, more likely to be related to changes in factor proportions.

For the sample using labour classified by occupation the results are different. The estimated coefficient for the RFP variable is statistically significant only with the pooled (OLS) estimator. The estimated coefficient for the PFP variable is statistically significant and positive with the pooled (OLS) estimator at 95\% confidence and the GMM estimator (at 99\%) but not with the fixed effects panel estimator. 
TABLE 5: REGRESSION ESTIMATES, USING STOCKS OFINWARD FDI

A. using labour classified by educational requirements

Cross-sections (factors) included: 21

Total panel (balanced) observations: 147

Dependent Variable: Factor Content of Stocks of Inward FDI (RS)

\begin{tabular}{|c|c|c|c|c|}
\hline Variable & Label & Estimator: & & \\
\hline & & Pooled & Panel & GMM \\
\hline & & (OLS) & (double fixed & (Arellano \\
\hline & & & effects) & Bond) \\
\hline \multirow[t]{2}{*}{ Constant } & C & $-4689.232^{*}$ & 13129.59 & \\
\hline & & $(2656.815)$ & $(31014.01)$ & \\
\hline \multirow[t]{2}{*}{ Lagged dependent variable (FDI) } & LFIS & & & $0.80186^{\star \star \star}$ \\
\hline & & & & $(0.08403)$ \\
\hline \multirow[t]{2}{*}{ Factor Content of Net Exports } & AT & $0.32875^{\star \star \star}$ & $1.2771^{\star \star *}$ & 1.16207 \\
\hline & & $(0.0944258)$ & $(0.40945)$ & $(0.9397)$ \\
\hline \multirow[t]{2}{*}{ Factor Content of Consumption } & $A C$ & $0.36018 * \star \star$ & $0.35604^{\star \star *}$ & $0.28328^{\star \star \star}$ \\
\hline & & $(0.040753)$ & $(0.04215)$ & $(0.09487)$ \\
\hline \multirow[t]{2}{*}{ Factor Composition of MFP } & FMFP & 36.79225 & -402.1912 & -1090.133 \\
\hline & & $(36.19527)$ & $(265.1842)$ & $(724.4817)$ \\
\hline \multirow[t]{2}{*}{ Factor Proportions } & RFP & $-115353^{\star \star *}$ & $-68428.29 * *$ & -84698.29 \\
\hline & & $(15352.23)$ & $(27766.26)$ & $(81917.76)$ \\
\hline \multirow[t]{2}{*}{ Proportionate Change in Factor Intensity } & PFP & 1411.468 & 6182.403 & $141130.1^{* * *}$ \\
\hline & & $(4354.027)$ & $(4559.496)$ & $(60686.8)$ \\
\hline R-squared & & 0.5056 & 0.7557 & \\
\hline Adjusted R-squared & & 0.4881 & 0.6898 & \\
\hline Explained sum of squares & & $6.73 \mathrm{E}+10$ & $8.66 \mathrm{E}+10$ & \\
\hline Residual sum of squares & & 4.05E+10 & $2.12 \mathrm{E}+10$ & \\
\hline F-statistic & & 28.8400 & 11.4741 & \\
\hline
\end{tabular}

\section{B. using labour classified by occupation (US SOC)}

Cross-sections (factors) included: 20

Total panel (balanced) observations: 140

Dependent Variable: Factor Content of Stocks of Inward FDI (RS)

\begin{tabular}{|c|c|c|c|c|}
\hline \multirow[t]{4}{*}{ Variable } & & \multicolumn{2}{|l|}{ Estimator: } & \multirow[b]{2}{*}{ GMM } \\
\hline & & Pooled & Panel & \\
\hline & & (OLS) & (double fixed & (Arellano \\
\hline & & & effects) & Bond) \\
\hline \multirow[t]{2}{*}{ Constant } & C & -1288.591 & -13608.53 & \\
\hline & & $(2477.886)$ & $(17299.8)$ & \\
\hline \multirow[t]{2}{*}{ Lagged dependent variable (FDI) } & LFIS & & & $0.8018 * \star \star$ \\
\hline & & & & $(0.0840)$ \\
\hline \multirow[t]{2}{*}{ Factor Content of Net Exports } & AT & $0.36134^{\star * \star}$ & $2.38133^{\star \star \star}$ & 1.16207 \\
\hline & & $(0.11535)$ & $(0.413347)$ & $(0.93970)$ \\
\hline \multirow[t]{2}{*}{ Factor Content of Consumption } & $A C$ & $0.31027^{\star \star \star}$ & $0.31607 * * *$ & $0.28328^{* \star *}$ \\
\hline & & $(0.03082)$ & $(0.03157)$ & $(0.09487)$ \\
\hline \multirow[t]{2}{*}{ Factor Composition of MFP } & FMFP & 52.72699 & $-499.03^{* * *}$ & -1090.133 \\
\hline & & $(61.0062)$ & $(169.11)$ & $(724.4817)$ \\
\hline \multirow[t]{2}{*}{ Factor Proportions } & RFP & $-357131.4^{* * *}$ & -20157.93 & -84698.29 \\
\hline & & $(47148.8)$ & $(84645.7)$ & $(81917.76)$ \\
\hline \multirow[t]{2}{*}{ Proportionate Change in Factor Intensity } & PFP & $17250.41^{* *}$ & 3152.165 & $141130.1^{\star * \star}$ \\
\hline & & $(8948.29)$ & $(8898.33)$ & $(60686.8)$ \\
\hline$\overline{\text { R-squared }}$ & & 0.562999 & 0.798366 & \\
\hline Adjusted R-squared & & 0.546693 & 0.74287 & \\
\hline Explained sum of squares & & $4.88 \mathrm{E}+10$ & $6.91 \mathrm{E}+10$ & \\
\hline Residual sum of squares & & $3.79 \mathrm{E}+10$ & $1.75 \mathrm{E}+10$ & \\
\hline F-statıstıc & & 34.53 & 14.38611 & \\
\hline
\end{tabular}

\section{NOTES:}

Figures in parentheses are standartd errors (for pooled and panel regressions) or

robust standard errors (GMM estimator)

$\star \star * *$ indicates statistically significant at $99 \%$

** indicates statistically significant at $95 \%$

** indicates statistically significant at $90 \%$ 


\section{CONCLUSIONS}

A number of authors, including Blonigen (2005), have commented on the relative scarcity of empirical work on the location of inward FDI. One promising strand within this literature is the role of skilled labour. However, as Pfluger et al (2010) note, this is often represented as a simple dichotomy between skilled and unskilled labour. This paper offers a contribution to the literature which allows for multiple labour categories. Moreover, following the insight of Dunning (1998) that factor proportions theory needs to be better integrated with the location of FDI, it provides a methodological approach which is grounded in the factor proportions literature. Like almost all of the relevant literature it is intended to increase our understanding the environment in which FDI and international business operates, an issue of relevance to management.

This study finds that the available evidence on US inward FDI is focused on economic activities which make intensive use of skilled labour - hypothesis 1. Although this is a good simple generalisation, reality is a little more complex. For example, some of the highest categories of educated labour tend to be employed in sectors such as education or health which do not attract high volumes of inward FDI. The evidence presented here also supports hypothesis 2 - that those industries with high multi-factor productivity growth in the US are also those which make more intensive use of highly skilled labour. Industries with high growth are not uniquely characterised by the use of skilled labour but also, in particular, the use of computers and computer services.

If both inward FDI and multifactor productivity growth are associated with the use of highly skilled labour then it would be reasonable to expect a statistically significant relationship between inward FDI and multifactor productivity growth - hypothesis 3. Regression analysis does not support this hypothesis, with the results using different estimators and different samples producing almost universal statistically insignificant results. Since the relevant variable is very highly correlated with two other explanatory variables it is probable that this conclusion is affected by multicollinearity.

The regression results generally support the view that US net exports are specialised in industries which make intensive use of the same factors of production (predominantly highly skilled labour) as does inward FDI - hypothesis 4 . The estimated coefficient for the factor content of net exports is positive and statistically significant for both pooled (OLS) and panel estimators. With a GMM estimator the estimated coefficient is still positive but not statistically significant.

The regression results also support a statistically significant and positive relationship between the factor content of inward FDI and that of consumption - hypothesis 5. The relevant coefficient is positive and statistically significant with all three estimators and in both samples. This result suggests that skilled labour and strategic asset seeking motives overlap with market seeking motives in US inward FDI. Finally, the results with respect to skill (factor) biased technical change are not statistically significant with static estimators (OLS and panel) but are positive and statistically significant with the dynamic GMM estimator. 
Since a dynamic estimator is more appropriate to technical change there is some evidence to suppose that US inward FDI is focused in industries with high skill biased technical change.

Overall, the contribution of the paper is to model the determinants of FDI based on OLI theory and re-state it in terms of factors rather than firms or industries. The main objective was to provide an analysis of the role of skilled labour but it also provides an analysis of the determinants of inward FDI. Specifically, it provides evidence that strategic asset seeking behaviour, combined with efficiency seeking and market seeking are the main drivers of US inward FDI. 


\section{REFERENCES}

Berman, E, Bound, J and Griliches, Z (1994). Changes in the Demand for Skilled Labour within U.S. Manufacturing: Evidence from the Annual Survey of Manufactures, Quarterly Journal of Economics, 109,367-397.

Berman, E, Bound, J and Machin, S (1998). Implications of Skill Biased Technical Change: International Evidence, Quarterly Journal of Economics, 113, 1245-1280.

Blonigen, B.A., (2005). A Review of the Empirical Literature on FDI Determinants, Atlantic Economic Journal, 33, 383-403.

Buckley, P, and Casson, M,(1976). The Future of the Multinational Enterprise (Vol. 1). London: Macmillan.

Cantwell, J and Janne, O (1999). Technological Globalisation and Innovative Centres: The Role of Corporate Technological Leadership and Locational Hierarchy, Research Policy, 28, 119-144.

Cantwell, J (2009). Location and the Multinational Enterprise, Journal of International Business Studies, 40, 35-41.

Carr, D, Markusen, J, and Maskus, K, (2001). Estimating the Knowledge-Capital Model of the Multinational Enterprise, American Economic Review, 91, 2001, pp. 693-708.

Chidlow, A., Salciuviene, L., \& Young, S., (2009), Regional determinants of inward FDI distribution in Poland, International Business Review, 18, 119-133

Chung, W and Alcacer, J (2002). Knowledge Seeking and Location Choice of Foreign Direct Investment in the United States, Management Science, 1534-1554.

Driffield, N (2001). The Impact on Domestic Productivity of Inward Investment in the UK, The Manchester School, 69, 103-119.

Driffield, N (2002), Determinants of Inward Investment in the UK, a Panel Analysis, Applied Economics, 34, 555-560.

Driffield, N, Love, J, \& Taylor, K, (2009). Productivity and Labour Demand Effects of Inward and Outward Foreign Direct Investment on UK Industry, The Manchester School, 77, 171-203.

Driffield, N and Munday, M (2002). Industrial Performance, Agglomeration and Foreign Manufacturing Investment in the UK, Journal of International Business Studies, 31, 21-37.

Dunning, J. H. (1988). The Eclectic Paradigm of International Production: a Restatment and Some Possible Extensions. Journal of International Business Studies, 19, 1-31.

Dunning, J.H. (1998) Location and the Multinational Enterprise: A Neglected Factor? Journal of International Business Studies, 29, 45-66.

Dunning, J.H., (2000). The eclectic paradigm as an envelope for economic and business theories of MNE activity, International Business Review, 9, 163-190.

Dunning, J. H., \& S. M. Lundan. (2008). Multinational Enterprises And The Global Economy. Cheltenham, UK: Edward Elgar. 
Dunning, J.H. (2009) Location and the Multinational Enterprise: John Dunning's Thoughts on Receiving the Journal of International Business Studies 2008 Decade Award, Journal of International Business Studies, 40, 20-34.

Elia, S, Mariotti, I, and Piscitello, L, (2009). The Impact of Outward FDI on the Home Country's Labour Demand and Skill Composition. International Business Review, 18(4), 357372.

Haskel, J (2000). Trade and Labour Approaches to Wage Inequality. Review of International Economics, 8, 397-408.

Kleinert, J, and Toubal, F, (2010). Gravity for FDI, Review of International Economics, 18, 1-13.

Krugman, P (2000). Technology, Trade and Factor Prices, Journal of International Economics, 50, 51-71.

Krugman, P. (2008). Trade and Wages, Reconsidered, Brookings Papers on Economic Activity, 2008(1), 103-154.

Leamer, E (1980). The Leontief Paradox Reconsidered, Journal of Political Economy, 88, 1040-1043.

Leamer, E (2000). Whats the Use of Factor Contents ?, Journal of International Economics, $50,17-49$.

Machin, S, (2001). The Changing Nature of Labour Demand in the New Economy and SkillBiased Technology Change, Oxford Bulletin of Economics and Statistics, 63, 753-776.

Mariel, P., Orbe, S., and Rodríguez, C. (2009). The Knowledge-Capital Model of FDI: A Time Varying Coefficients Approach, Scottish Journal of Political Economy, 56, 196-212.

Maskus, K and Webster, A (1995). Comparative Advantage and the Location of Inward Foreign Direct Investment: Evidence from the UK and South Korea, World Economy, 18, 315-328.

Milner, C and Pentecost, E (1996), Locational Advantage and US Foreign Direct Investment in UK Manufacturing, Applied Economics, 28, 605-615.

Nachum, L, Dunning, J and Jones, G (2000). UK FDI and the Comparative Advantage of the UK, World Economy, 23, 701-720.

Palangkaraya, A and Waldkirch, A, (2008). Relative Factor Abundance and FDI Factor Intensity in Developed Countries, International Economic Journal, 22, 489-508.

Papadopoulos, N, and Martín Martin, O. (2010). Toward aModel of the Relationship Between Internationalization and Export Performance. International Business Review, 19, 388-406. 
Pflüger, M., Blien, U., Möller, J., \& Moritz, M. (2010). Labor market effects of trade and FDI: Recent advances and research gaps. Discussion paper series // Forschungsinstitut zur Zukunft der Arbeit, No. 5385, http://hdl.handle.net/10419/52008

Piva, M, Santarelli, E and Vivarelli, M (2005). The Skill Bias of Technological and Organisational Change, Research Policy, 34, 141-157.

Trefler, D (1995). The Case of the Missing Trade and Other Mysteries. American Economic Review, 85, 1029-1046.

Uddin, M. \& Boateng, A., (2011). Explaining the Trends in the UK Cross-Border Mergers \& Acquisitions: An Analysis of Macro-Economic Factors, International Business Review, 20, 547-556.

Vanek, J (1968). The Factor Proportions Theory: The N-Factor Case, Kyklos, 21, 749-756.

Villaverde, J., \& Maza, A., (2012). Foreign direct investment in Spain: regional distribution and determinants, International Business Review, 21, 722-733

Wood, A (1993). Give Hecksher and Ohlin a Chance, Review of World Economics, 130, 20 49.

Yeaple, S (2003). The Role of Skill Endowments in the Structure of U.S. Outward Foreign Direct Investment, Review of Economics and Statistics, 85, 726-734.

Zwinkels, R.C.J., \& Beugelsdijk, S., (2010). Gravity equations: workhorse or trojan horse in explaining trade and FDI patterns across time and space?, International Business Review, 19,102-115 